\title{
Subdural hematomas: glutaric aciduria type 1 or abusive head trauma? A systematic review
}

\author{
Marloes E. M. Vester ${ }^{1,2}$ (D) Rob A. C. Bilo ${ }^{2}$ Wouter A. Karst ${ }^{2} \cdot$ Joost G. Daams $^{3}$ • \\ Wilma L. J. M. Duijst ${ }^{4}$ Rick R. van Rijn ${ }^{1,2}$
}

Accepted: 10 July 2015/Published online: 29 July 2015

(C) The Author(s) 2015. This article is published with open access at Springerlink.com

\begin{abstract}
Purpose Glutaric aciduria type 1 (GA1) is a rare metabolic disorder of glutaryl-CoA-dehydrogenase enzyme deficiency. Children with GA1 are reported to be predisposed to subdural hematoma (SDH) development due to stretching of cortical veins secondary to cerebral atrophy and expansion of CSF spaces. Therefore, GA1 testing is part of the routine work-up in abusive head trauma (AHT). This systematic review addresses the coexistence of GA1 and SDH and the validity of GA1 in the differential diagnosis of AHT.

Methods A systematic literature review, with language restriction, of papers published before 1 Jan 2015, was performed using Pubmed, PsychINFO, and Embase. Inclusion criteria were reported SDHs, hygromas or effusions in GA1 patients up to 18 years of age. Of 1599 publications, 20 publications were included for analysis.

Results In total 20 cases, 14 boys and 6 girls, were included. In eight cases (40\%) a child abuse work-up was performed, which was negative in all cases. Clinical history revealed the presence of trauma in eight cases $(40 \%)$. In only one case neuroradiology revealed no abnormalities related to GA1 according to the authors, although on evaluation we could not exclude AHT.
\end{abstract}

Marloes E. M. Vester

marloes.vester@gmail.com

1 Department of Radiology, Academic Medical Center, Room G1-213, Meibergdreef 9, 1105 AZ Amsterdam, The Netherlands

2 Department of Forensic Medicine, Netherlands Forensic Institute, The Hague, The Netherlands

3 Medical Library, Academic Medical Center, Amsterdam, The Netherlands

4 GGD IJsselland, Zwolle, The Netherlands
Conclusion From this systematic review we conclude that SDHs in 19/20 children with GA1 are accompanied by other brain abnormalities specific for GA1. One case with doubtful circumstances was the exception to this rule.

Keywords Metabolic disorder - Glutaric aciduria type 1 . Subdural hematoma Abusive head trauma Forensic radiology

\section{Introduction}

Subdural hematomas (SDHs) in children, especially under two years of age, are a common finding in abusive head trauma (AHT). This refers to inflicted cranial, cerebral, and spinal injuries due to blunt force trauma (e.g., acceleration or deceleration trauma), inertial trauma (e.g., repetitive acceleration-deceleration trauma), or a combination of factors [1, 2]. In contrast it has been reported that SDHs are estimated to be present, without significant trauma, in 20-30\% of children with glutaric aciduria type 1 (GA1) [3-8]. GA1 is a rare, autosomal recessive, metabolic disorder caused by a deficiency of riboflavin-dependent glutaryl-CoA dehydrogenase. Glutaryl-CoA dehydrogenase is a mitochondrial matrix enzyme which helps to convert the proteins lysine, hydroxylysine, and tryptophan to acetoacetyl-CoA. The deficiency of this enzyme results in accumulation of the neurotoxic breakdown products glutaric acid and 3-hydroxy-glutaric acid [9, 10]. The first patient description of GA1 was 1975, since then over 200 mutations have been described [11, 12]. The disorder is estimated to have a world-wide birth prevalence of 1 in 100,000 with new-born screening methods [13, 14]. Twenty-five percent of patients remain unaffected, independent of their genotype $[15,16]$. The clinical 
presentation of GA1 is very variable, even within families [17]. Macrocephaly is present at birth in most cases or else it develops shortly after birth. Prior to the new-born screening program most children first were presented, between the ages of 3-36 months, due to an encephalic crisis [18-22]. This encephalic crisis is mostly seen after a febrile illness and may result in bilateral striatal necrosis with dystonia, orofacial dyskinesia, and choreathetosis with an initially preserved cognitive function [16, 23]. As GA1, if diagnosed and treated early, is considered to be a treatable disorder it is part of the new-born screening programs in various countries [24, 25].

Neuroimaging studies of GA1 patients are among others characterized by widening of the Sylvian fissures (open opercula), widened mesencephalic cisterns, expansion of CSF spaces anterior to the temporal lobes (Fig. 1) [4, 26]. These brain anomalies are the result of abnormal growth rather than atrophy and this has also been named micrencephalic macrocephaly [27]. In GA1 widening of the subarachnoid space can lead to tension on bridging veins which in turn are more susceptible to rupture, even after minor trauma, leading to SDHs. The presence of SDHs might be a diagnostic pitfall in the diagnosis of GA1, because SDHs can be misdiagnosed as the result of AHT. Based on this many pediatric guidelines recommend to consider GA1 in cases of SDHs due to suspected AHT [8, 25]. Diagnosis of GA1 might be life-saving and accordingly prevent false accusations and family disruption [16]. Nevertheless, from a clinic-forensic perspective it is

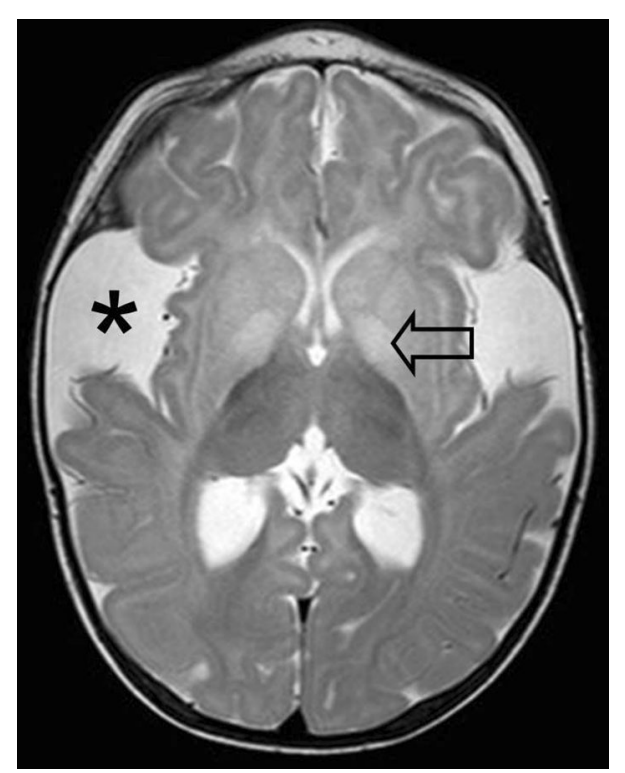

Fig. 1 Six month old girl with known GA1. T2 weighted MRI (TR 3944, TE 80, Flip angle $90^{\circ}$, slice thickness $3 \mathrm{~mm}$ ) shows widening of the Sylvian fissures (asterisk) and a high signal intensity of the basal ganglia (arrow) important to note that diagnosis of GA1 does not exclude AHT [28].

The purpose of this study was to describe and analyze published SDH cases in children with GA1. A systematic review was performed to address the following research questions; is AHT considered and ruled out in case of a SDH in children with GA1? Was GA1 known at the time of presentation with SDH? Is there, based on the literature, a role for GA1 in the differential diagnosis of SDHs in AHT?

\section{Materials and methods}

\section{Search strategy}

A systematic literature search was performed in MEDLINE (Pubmed), EMBASE (OvidSP), PsychINFO (OvidSP), CINAHL, and the Cochrane library, for abstracts and articles up to $1 \mathrm{Jan} 2015$. It consisted of an indexed search with terms of glutaric aciduria type 1 , non-accidental injury, child abuse, abusive head trauma, and subdural hematoma, performed by a literature search expert (JD). Publication language was restricted to English, German, French, and Dutch. Publication status was not restricted. In addition, citation tracking was performed in Google Scholar, Pubmed, and Web of Science. An overview of the search strategy can be given on request.

\section{Study selection}

All identified articles, once scanned for duplicates, were screened by two researchers (R.R. and M.V.) for eligibility. In case of disagreement between the two researchers on either the evidence type of the article or whether the study met the inclusion criteria, a consensus was met after discussion. Titles were selected based on GA1 patient descriptions, a GA1 neurosurgical perspective or neuroimaging, and metabolic disorders combined with abuse, neuroimaging or SDHs. Selected abstracts were evaluated based on GA1 with SDHs, neuroimaging, neurosurgery or macrocephaly. After abstract selection, full articles were obtained and appraised. The references cited in the included full articles were manually examined for identification of additional relevant articles.

In the non-abused children ranking of exclusion of abuse was based on the Cardiff Child Protection Systematic Reviews [29]. This ranking system consists of the following categories: type A1 independently witnessed accidental cause or forensic recreation of scene; A2 by confirmation of organic disease (diagnostic test and/or diagnosis from clinical profile); B1 by multi-disciplinary assessment and child protection clinical investigation; B2 consistent account of accident by the same individual over time; B3 
by checking either the child abuse register or records of previous abuse; $\mathrm{C} 1$ accidental cause/organic diagnosis stated but no detail given; $\mathrm{C} 2$ no attempt made to exclude abuse/no detail given. Studies were included if they had: (1) human study objects up to 18 years old, (2) study objects diagnosed with GA1, and (3) confirmed SDHs with $\mathrm{CT}$ and/or MRI scans. If studies did not relate which data belonged to which specific case, GA1 wasn't confirmed, or no neuroimaging of $\mathrm{SDH}$ was available, they were excluded.

\section{Quality assessment}

Based on criteria defined by the National Health Service's Centre for Reviews and Dissemination and the CORE database, standardized data extraction and critical appraisal forms were used [29, 30]. Methodological quality assessment was performed by two individual researchers (R.R. and M.V.) using an adapted form of the Critical Appraisal Skills Program (CASP) (available upon request) [31].

\section{Data extraction}

Data extraction was performed by one reviewer (M.V.), using a structured case report form (available upon request). The extracted data, at a patient level, were the following:

- Study design, patient characteristics (age, gender), author, year of publication, country, related family with GA1, and confirmed GA1 at time of SDH presentation.

- Type of imaging, other cerebral abnormalities at time of SDH presentation, clinical signs, and outcome.

- Consideration of AHT, steps taken to investigate this possibility (medically, legally, and socially) and investigation of SDH origin. Ranking of exclusion of child abuse according to CORE INFO [29].

\section{Results}

\section{Study identification}

The initial literature search yielded 1599 publications, after title and abstract selection 108 articles remained for full text evaluation (Fig. 2). Based on the analysis of the references cited in the included full texts we included five additional publications. However, none of these publications contained sufficient information for inclusion in our systematic review.
A total of 22 publications were selected, and three of the authors of these publications were contacted for additional information. One article was not eligible for inclusion because it contained insufficient information [27]. Furthermore, two articles described the same case, so only the article by Muntau et al. [7, 32] was included. Twenty articles were included in the final study, each of these containing 1 eligible patient description (Table 1) $[3,8,16$, 32-48]. This resulted in an inclusion of in total 20 children with GA1 and SDHs in this review.

\section{Study quality}

The 20 articles consisted of 4 case series and 16 case reports $[34,39]$. Higher evidence levels than level 4 and 5 of case reports and case series were not available.

\section{Subdural hematoma's in children with glutaric aciduria type 1}

The included cases consisted of 14 boys ( $80 \%$ ) with a median age of 10 months (range 8 weeks-2 years) and 6 girls with a median age of 14 months (range 6-23 months) (Table 2). Of all cases only patient number 3 did not have an enlarged head circumference or macrocephaly defined as $>2$ SD. The head circumferences of child 1 and 17 were not reported.

Heredity was apparent in four cases; child 12 and 20 had consanguine parents. Moreover, patient 1 was born from consanguine parents and also had GA1 affected relatives. The disorder was diagnosed prenatally in child 6 because of a brother with GA1. The confirmation of a GA1 diagnosis was at a median age of 12 months for boys and 22 months for girls. In four cases $(20 \%)$ the disease was already confirmed prior to presentation with a $\operatorname{SDH}(1,6,9$, and 19). One of these, child 19, was identified by new-born screening.

In 18 out of 20 cases (6 and 7) urine screening tests with elevated levels of glutaric acid and/or 3-hydroxyglutaric were reported (Table 2). Enzyme activity was reported to be absent in 5 cases, decreased in 2 and not reported in 13 $(65 \%)$. All children started medical and dietary treatment once the diagnosis GA1 was established. Surgical intervention for the SDH was performed in 13 children $(65 \%)$, of which four received a ventricular-peritoneal shunt, three a subdural shunt and six drainage through either craniotomy or burr holes.

\section{Abusive head trauma work-up}

For eight cases (40\%) a child abuse work-up was performed, four had a social background check and/or clinical history investigation, two had coagulation tests, five 
Fig. 2 Flowchart literature search

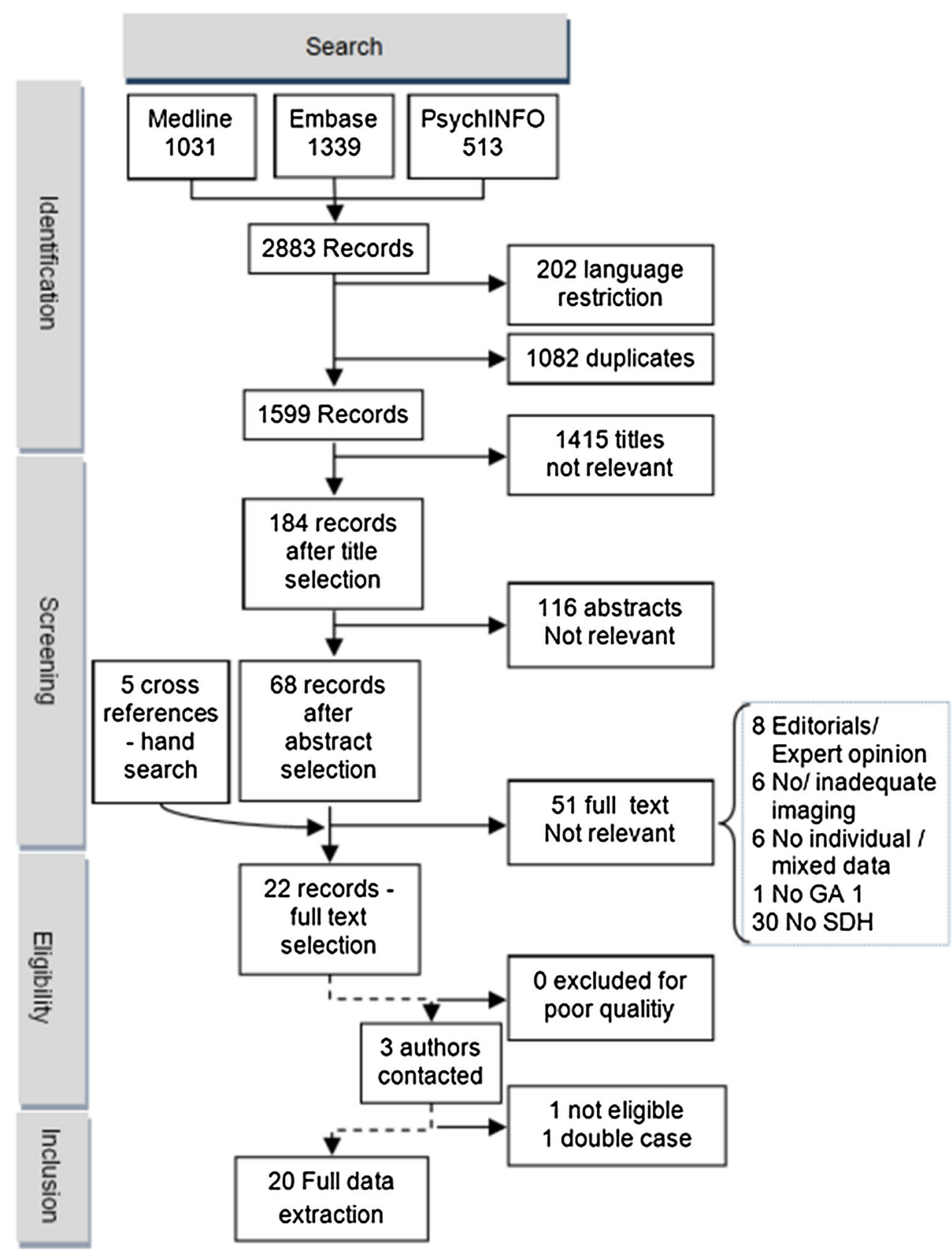

underwent skeletal surveys (of which 1 was a skeletal scintigraphy) and seven children underwent ophthalmologic assessment. In none of these cases child abuse was confirmed, although child 8 remained in the care of social services. Clinical history revealed head trauma in eight cases (40\%), varying from falling while kneeling to falling off a flight of stairs. Eleven cases did not report any cause for SDH development and one case presented after a metabolic crisis due to infection. In conclusion, child abuse was excluded in seven cases with a rank B1, in three children with rank B2 and in ten children no attempt was made to exclude abuse or at least this was not reported in the case report (rank C2) [29].

\section{Neuroimaging of SDHs and GA1}

SDH neuroimaging was performed with a CT-scan in 13 cases, 13 with an MRI and 1 with ultrasound. Abnormalities of the brain were visible in 19 cases (95\%), these abnormalities were fronto-parietal brain atrophy in 19 (95\%), open opercula in $18(90 \%)$, white matter abnormalities in $7(35 \%)$, arachnoid cysts in $1(5 \%)$, ventricular 
Table 1 Included articles

\begin{tabular}{lllll}
\hline Article & First author and ref. no. & Year & Journal & Country \\
\hline 1 & Amir [33] & 1989 & J. Pediatr. & Denmark \\
2 & Land [41] & 1992 & Neuropediatrics & UK \\
3 & Osaka [43] & 1993 & Brain Dev. & Japan \\
4 & Woelfe [8] & 1996 & Pediatr. Radiol. & Germany \\
5 & Pfluger [44] & 1997 & Eur. Radiol. & Germany \\
$6^{a}$ & Muntau [32] & 1997 & Monatsschr. Kinderheilkd. & Germany \\
7 & Lütcherath [42] & 2000 & Acta. Neurochir. & Norway \\
8 & Hartley [16] & 2001 & Pediatrics & UK \\
9 & Knapp [47] & 2002 & Pediatr. Emerg. Care & USA \\
10 & Desai [35] & 2003 & Invest. Radiol. & USA \\
11 & Gago [37] & 2003 & Retina & USA \\
12 & Elsori [36] & 2004 & East. Mediterr. Health J. & Kuwait \\
13 & Singh [46] & 2006 & Ind. J. Radiol. Imaging & India \\
14 & Hou [38] & 2007 & J. Neurosurg. & USA \\
15 & Bishop [3] & 2007 & J. Neurosurg. & USA \\
16 & Kamate [39] & 2009 & Ind. J. Pediatr. & India \\
17 & Carman [34] & 2012 & J. Pediatr. Child. Health & Turkey \\
18 & Kim [40] & 2014 & An. Clin. Lab. Sci. & Korea \\
19 & Zielonka [48] & 2014 & J. Child. Neurol. & Germany \\
20 & Pusti [45] & 2014 & Case Rep. Pediatr. & India \\
\hline
\end{tabular}

a Same patient also described by Köhler et al. [7]

dilatation and/or widening CSF spaces in $8(40 \%)$, and basal ganglia attenuation in 9 (45\%) (Table 3).

Only one case, presented in the case report by Knapp et al. [47], revealed no neuroradiological abnormalities in keeping with GA1. The authors present the case of a 9-month old boy who was seen after a backward fall while kneeling, resulting in brief stiffness followed by limpness for 5-10 min and perioral cyanosis. At the ER a CT-scan of the brain showed no abnormalities. A day later he started to vomit, at that time the ED physician diagnosed otitis media and he was sent home. Two days later he was admitted to the same community hospital because of vomiting and subsequent dehydration. At this time a CT revealed a rightsided isoattenuating parietal subdural hematoma. No intervention was performed and, as on the next morning he was doing well, he was sent home again. Six weeks later the boy reportedly fell off the furniture resulting in stiffness, rhythmic jerking of all extremities, 5 min loss of consciousness, irritability, and vomiting. On CT bilateral hypoattenuating extra axial fluid collections and a right acute subdural hemorrhage were seen for which a craniotomy with subdural drain placement was performed. He was transferred to a pediatric hospital where clinical history and physical examination revealed that the boy could not yet sit independently and had only recently started to crawl, he also showed mild hypotonia of the trunk, and relative macrocephaly. On ophthalmologic assessment there were multiple intraretinal hemorrhages, 1 subhyaloid hemorrhage and mild papilledema. There were no significant coagulation disorders or fractures on the skeletal survey. The child protection team advised GA1 testing, which was found to be positive. After interviewing the parents and careful evaluation, AHT diagnosis was rejected.

We contacted the authors of this case for additional information on the suspicion of child abuse and for supplementary CT-scan images. Unfortunately, patient information was de-identified for the authors and no additional information could be given. The case was reviewed by two forensic pediatric medical doctors (RB and WK) with respectively 27 and 7 years of experience in the field and a forensic pediatric radiologist (RR) with 12 years of experience. The clinical history, as reported, is insufficient from a forensic perspective. Ocular subhyaloid hemorrhages are not characteristic of GA1, it can be a result of migration hemorrhages due to retinal hemorrhages and/or retinoschisis, as can be seen in AHT [49, 50]. Furthermore the force of the initial impact, as described by the parents, is under normal circumstances insufficient to cause a SDH [51]. The predisposition in children with GA1 for the development of SDH is believed to be a result of stretching of cortical veins secondary to cerebral atrophy/hypoplasia and expansion of CSF spaces [38]. Conversely, it has been suggested that a metabolic crisis in GA1 children causes 
Table 2 Clinical information of included cases

\begin{tabular}{|c|c|c|c|c|c|c|c|}
\hline $\mathrm{Pt}^{\mathrm{a}}$ & $\mathrm{Age}^{\mathrm{b}}$ & Sex & $\begin{array}{l}\text { Medical history and } \\
\text { clinical signs }\end{array}$ & AHT & $\begin{array}{l}\text { CORE } \\
\text { score }^{\mathrm{c}}\end{array}$ & $\begin{array}{l}\mathrm{SDH} \\
\text { treatment }\end{array}$ & Outcome \\
\hline 1 & 18 Months & $\mathrm{F}$ & $\begin{array}{l}1 \text { Months GA1 diagnosis. } \\
\text { Mild psychomotor } \\
\text { retardation }\end{array}$ & NR & $\mathrm{C} 2$ & & $\begin{array}{l}\text { Diet and medication up till } \\
18 \text { months } \\
\text { Dystonic quadriplegia at } 3 \text {-year } \\
\text { old }\end{array}$ \\
\hline 2 & 19 Months & M & $\begin{array}{l}\text { Macrocephaly. Head trauma } \\
\text { (5-6 stairs); sleepy, } \\
\text { vomiting } \\
\text { +1 Day; alternating } \\
\text { consciousness, loss of } \\
\text { head control, impaired } \\
\text { speech and abnormal arm } \\
\text { extension }\end{array}$ & NR & $\mathrm{A} 2$ & VP shunt & $\begin{array}{l}\text { Right sided hemiparesis, } \\
\text { hypotonia, choreoathetosis. } \\
\text { +6 weeks CT; increase } \\
\text { subdural collection. } \\
24 \text { Months; normal movement, } \\
\text { tonus and speech improvement } \\
25 \text { Months; drain } \\
\text { infection > dystonia > urine/ } \\
\text { serum GA1 positive (previous } \\
\text { results negative) } \\
33 \text { Months; sudden death }\end{array}$ \\
\hline 3 & 6 Months & M & $\begin{array}{l}5 \text { Months: infection }>\text { focal } \\
\text { motor seizures, } \\
\text { involuntary movements. } \\
6 \text { Months: lethargic, } \\
\text { dystonic hypotonia, oral } \\
\text { dyskinesia }\end{array}$ & No trauma or abuse reported & $\mathrm{C} 2$ & $\begin{array}{l}\text { Bilateral } \\
\text { craniotomy }\end{array}$ & $\begin{array}{l}\text { Urine/fibroblast = GA1 positive } \\
10 \text { Months; clinical } \\
\text { improvement with } \\
\text { extrapyramidal symptoms }\end{array}$ \\
\hline 4 & 6 Months & $\mathrm{F}$ & $\begin{array}{l}\text { Macrocephaly }>\text { normal } \\
\text { US. Loss of head control, } \\
\text { moderate trunk hypotonia }\end{array}$ & No trauma & $\mathrm{C} 2$ & $\begin{array}{l}\text { Left sided } \\
\text { drainage } \\
\text { and VP } \\
\text { shunt }\end{array}$ & $\begin{array}{l}9 \text { Months; progressive motor loss } \\
\text { and dystonia. MRI: rest SDH } \\
\text { Urine/fibroblast: GA1 positive }\end{array}$ \\
\hline 5 & 11 Months & $\mathrm{F}$ & $\begin{array}{l}\text { Macrocephaly. Unclear } \\
\text { head trauma; unconscious } \\
\text { for hours, somnolence, } \\
\text { muscle hypotonia and } \\
\text { seizures }\end{array}$ & $\begin{array}{l}\text { Social, clinic and radiology } \\
\text { misinterpreted as battered child } \\
\text { syndrome }\end{array}$ & B1 & Shunt & $\begin{array}{l}\text { +3-Year; loss of psychomotor } \\
\text { function, dystonic-dyskinesia } \\
\text { syndrome } \\
\text { +4-Year; reanalysis > positive } \\
\text { GA1 analysis }\end{array}$ \\
\hline
\end{tabular}

68 Months M Macrocephaly, 6 months; truncal hypotonia.

Ophthalmology; bilateral multiple 8 Months; fall from stairs; vomiting, somnolence, irritability, skin hematoma pin-point hemorrhages, AHT with parents discussed yet excluded after normal skeletal survey

7 1-Year M Macrocephaly, delayed NR

At 3-year old no symptoms motor development. Acute encephalitis-like syndrome

8 Weeks M Mother 25-year old; cognitive impaired; social services involved

Head against the wall by brother; vomiting, somnolence, right sided seizures. Macrocephaly
X-scull; no fractures. Normal coagulation. Skeletal survey: fractures right radius and metaphysic distal radius + periosteal reaction. Ophthalmology: 1 pinpoint hemorrhage right fundus
$\mathrm{C} 2$

Craniotomy
and VP
shunt

B1 Drainage: blood
Deterioration after operation

2.5 Year; GA1 diagnosed

3-Year; death after metabolic crisis

+2 Weeks; AHT charges made by the police $>$ temporary foster care

6 Months; developmental delay, bilateral hearing loss > urine/fibroblast: GA1 positive

Radius fracture was a vein, charges against mother suspended, however the child remained in foster care 
Table 2 continued

\begin{tabular}{|c|c|c|c|c|c|c|c|}
\hline $\mathrm{Pt}^{\mathrm{a}}$ & $\mathrm{Age}^{\mathrm{b}}$ & Sex & Medical history and clinical signs & AHT & $\begin{array}{l}\text { CORE } \\
\text { score }^{c}\end{array}$ & $\begin{array}{l}\text { SDH } \\
\text { treatment }\end{array}$ & Outcome \\
\hline 9 & 9 Months & M & $\begin{array}{l}\text { Fall backwards from kneeling; } \\
\text { stiffness > hypotonia with perioral } \\
\text { cyanosis } 5-10 \text { min, normal CT. } \\
\text { +1 days; vomiting (ear infection), } \\
\text { +3 days; vomiting, dehydration }\end{array}$ & $\begin{array}{l}\text { Loss of body control, no } \\
\text { bleeding/family disorders, } \\
\text { relative macrocephaly } \\
\text { Ophthalmology: multiple } \\
\text { intra retinal }+1 \\
\text { subhyaloid } \\
\text { hemorrhage + papilledema } \\
\text { Skeletal survey; normal }\end{array}$ & B1 & $\begin{array}{l}\text { Craniotomy } \\
\text { and } \\
\text { subdural } \\
\text { drain }\end{array}$ & $\begin{array}{l}+6 \text { Weeks fall from furniture; } \\
\text { stiffness, rhythmic seizures all } \\
\text { extremities, } 5 \text { min unconscious, } \\
\text { and vomiting. Serum/urine: GA1 } \\
\text { positive } \\
\text { Infection > subdural-peritoneal } \\
\text { shunt. Eventually gastrostomy, } \\
\text { seizures and severe } \\
\text { dystonia }>\text { bilateral pallidotomy }\end{array}$ \\
\hline 10 & 9 Months & M & $\begin{array}{l}\text { Cyanosis, diarrhea, transient left focal } \\
\text { seizures, shoulder girdle weakness, } \\
\text { macrocephaly }\end{array}$ & $\begin{array}{l}\text { Ophthalmology: bilateral } \\
\text { retinal hemorrhages, no } \\
\text { AHT reported }\end{array}$ & $\mathrm{C} 2$ & & $\begin{array}{l}30 \text { Months; mild choreoathetosis } \\
\text { and psychomotor retardation }\end{array}$ \\
\hline 11 & 6 Months & M & Macrocephaly and developmental delay & $\begin{array}{l}\text { Ophthalmology: bilateral } \\
\text { intraretinal + right sided } \\
\text { vitreous hemorrhages. } \\
\text { Skeletal survey normal }\end{array}$ & B1 & Drainage & $\begin{array}{l}\text { Urine: GA1 positive } \\
4 \text { Months; improvement of } \\
\text { symptoms }\end{array}$ \\
\hline 12 & 10 Months & M & $\begin{array}{l}\text { Macrocephaly } \\
5 \text { Months; meningitis } \\
+1 \text { Weeks fever, cough, vomiting. Short } \\
\text { left sided seizures, later right sided } \\
+5 \text { Days hemiplegia }\end{array}$ & NR & $\mathrm{C} 2$ & & $\begin{array}{l}\text { Urine/fibroblast: GA1 positive } \\
3.5 \text { Year; no seizures and mild } \\
\text { improvement hemiplegia }\end{array}$ \\
\hline 13 & 8 Months & M & $\begin{array}{l}\text { Macrocephaly, motor delay, milestone } \\
\text { regression, dystonia, dysarthria and } \\
\text { dyskinesia }\end{array}$ & NR & $\mathrm{C} 2$ & & Urine: GA1 positive \\
\hline 14 & 9 Months & M & Macrocephaly. & $\begin{array}{l}\text { Ophthalmology normal; AHT } \\
\text { excluded } \\
\text { Urine }>\text { GA1 positive }\end{array}$ & B1 & $\begin{array}{l}\text { Bilateral burr } \\
\text { holes }\end{array}$ & $\begin{array}{l}+2 \text { Months; new right subdural } \\
\text { collection; complete resolution } \\
\text { in time }\end{array}$ \\
\hline 15 & 7 Months & $\mathrm{F}$ & $\begin{array}{l}\text { Macrocephaly, mild hypotonia and } \\
\text { milestone delay }\end{array}$ & $\begin{array}{l}\text { AHT suspicion, mother } \\
\text { denies } \\
\text { Ophthalmology and skeletal } \\
\text { survey; no signs for AHT }\end{array}$ & B1 & $\begin{array}{l}\text { Bilateral } \\
\text { subdural } \\
\text { drains }\end{array}$ & $\begin{array}{l}11 \text { Months; macrocephaly, } \\
\text { improvement hypotonia and } \\
\text { head control, normal milestone } \\
\text { development }\end{array}$ \\
\hline 16 & 2-Year & M & 'Breath-holding spells' and macrocephaly & NR & $\mathrm{C} 2$ & Drainage & $\begin{array}{l}\text { Increase of macrocephaly and } \\
\text { hypotonia }\end{array}$ \\
\hline 17 & 17 Months & $\mathrm{F}$ & $\begin{array}{l}\text { Fall from chair with single generalized } \\
\text { seizure }\end{array}$ & NR & $\mathrm{A} 2$ & Operation & $\begin{array}{l}24 \text { Months; increase muscle tonus, } \\
\text { loss of milestone development }\end{array}$ \\
\hline 18 & 16 Months & M & $\begin{array}{l}\text { Multiple head trauma's, macrocephaly. } \\
\text { Complex febrile convulsions and } \\
\text { developmental delay, mild axial } \\
\text { hypotonia }\end{array}$ & NR & $\mathrm{C} 2$ & Burr holes & $\begin{array}{l}\text { New symptomatic infection } \\
\text { episode } \\
28 \text { Months; normal development }\end{array}$ \\
\hline 19 & 23 Months & $\mathrm{F}$ & $\begin{array}{l}\text { Macrocephaly. Head trauma }(50 \mathrm{~cm} \\
\text { fall) }>\text { vomiting } \\
+2 \text { Days generalized seizure, } \\
\text { unconsciousness, coma, anisocoria, less } \\
\text { pupil reflexes, respiratory insufficient }\end{array}$ & NR & A2 & $\begin{array}{l}\text { Left sided } \\
\text { hemi- } \\
\text { craniotomy } \\
\text { and VP } \\
\text { shunt }\end{array}$ & $\begin{array}{l}\text { Spastic tetraparesis, bilateral } \\
\text { dystonia, axial hypotonia and } \\
\text { bilateral pes equinus } \\
\text { +9 Months; improvement most } \\
\text { symptoms except axial } \\
\text { hypotonia and orofacial } \\
\text { dyskinesia }\end{array}$ \\
\hline 20 & 3 Months & M & $\begin{array}{l}\text { Progressive macrocephaly, insufficient } \\
\text { head control, motoric developmental } \\
\text { delay }\end{array}$ & $\begin{array}{l}\text { Normal blood count, no AHT } \\
\text { reported }\end{array}$ & $\mathrm{C} 2$ & & +3 Months normal head control \\
\hline
\end{tabular}

NI neuroimaging, SDH subdural hematoma, GAl glutaric aciduria type 1, CT computed tomography, MRI magnetic resonance imaging, US ultrasound, CSF cerebrospinal fluid

${ }^{a}$ Patient number correlates with article number in Table 1

b Age of patient at time of diagnosis of subdural hematoma

c Cardiff Child Protection Systematic Reviews, ranking of exclusion of abuse A1 independently witnessed accidental cause or forensic recreation of scene; A2 by confirmation of organic disease (diagnostic test and/or diagnosis from clinical profile); B1 by multi-disciplinary assessment and child protection clinical investigation; B2 consistent account of accident by the same individual over time; B3 by checking either the child abuse register or records of previous Abuse; $\mathrm{C} 1$ accidental cause/organic diagnosis stated but no detail given; $\mathrm{C} 2$ no attempt made to exclude abuse/no detail given [29] 
Table 3 Neuroradiological findings in included cases

\begin{tabular}{|c|c|c|c|c|c|c|c|}
\hline Pt no. ${ }^{a}$ & FLA & $\mathrm{OO}$ & BG & CSF & WA & $\mathrm{AC}$ & $\mathrm{SDH}$ \\
\hline 1 & + & + & - & + & + & - & + \\
\hline 2 & + & + & - & + & - & - & + \\
\hline 3 & + & + & - & - & - & - & + \\
\hline 4 & + & + & + & + & + & - & + \\
\hline 5 & + & + & - & + & - & - & + \\
\hline 6 & + & + & - & + & - & - & + \\
\hline 7 & + & + & - & - & - & + & + \\
\hline 8 & + & NR & - & - & + & - & + \\
\hline 9 & - & - & - & - & - & - & + \\
\hline 10 & + & + & + & + & + & - & + \\
\hline 11 & + & + & - & - & - & - & + \\
\hline 12 & + & + & - & - & - & - & + \\
\hline 13 & + & + & + & + & + & - & + \\
\hline 14 & + & + & + & - & - & - & + \\
\hline 15 & + & + & + & - & - & - & + \\
\hline 16 & + & + & + & - & + & - & + \\
\hline 17 & + & + & - & - & - & - & + \\
\hline 18 & + & + & + & - & - & - & + \\
\hline $19^{\mathrm{b}}$ & + & + & - & - & - & - & + \\
\hline 20 & + & + & + & + & + & - & + \\
\hline
\end{tabular}

FLA frontal lobe atrophy, $O O$ open opercula, $B G$ basal ganglia increased attenuation, $C S F$ ventricular and/or subarachnoid space dilatation, $W A$ white matter abnormalities, $A C$ arachnoid cysts, $S D H$ subdural hematoma, $N R$ not reported

${ }^{a}$ Patient number correlates with article number in Table 1

b Visible after decompressive surgery

cerebrovascular changes such as arteriolar dilatation, increased cerebral blood volume, and consequently venous hypertension possibly leading to SDH development [52]. At both injury times only the parents were around and therefore no independent witnesses can testify to what happened. In this case, lack of metabolic crisis symptoms, absence of widened subarachnoid spaces and otherwise normal appearance of the first CT scan, does not lead to an increased risk for SDH development. From a forensic point of view we therefore conclude that in this specific case AHT could not be completely ruled out.

\section{Discussion}

To our knowledge this is the first systematic review conducted on SDHs in children with the metabolic disorder of GA1. Twenty GA1 children with a SDH were identified in literature. All but the one case by Knapp et al. [47] were accompanied by other neuroimaging abnormalities specific for GA1. In 19 out of 20 cases cerebral imaging showed brain abnormalities specific for GA1. MRI and CT of the brain in these cases show widening of insular cisterns (Sylvian fissure/open opercula) in $93 \%$ of patients in the literature and $90 \%$ in this review [35, 53, 54]. These specific findings should therefore always lead to further investigation of GA1 [35]. Other distinctive cerebral changes reported in GA1 children with SDHs are comparable to reported GA1 cases without SDHs. Commonly this comprises of bilateral frontotemporal cortical atrophy or hypoplasia and sometimes enlargement of ventricles and mesencephalic cisterns [26, 35]. In 180 GA1 patients evaluated by Osaka et al. [43] abnormalities of the putamen, caudate nucleus, cortex, ventricles, and external CSF spaces were more often found on MRI in children with severe movement disorders. Notably changes of the putamen and enlarged ventricles are clinical important predictors of the severity of the disease [55]. Most of these abnormalities are detected during or after a metabolic crisis. Moreover on MRI these white matter abnormalities can improve after aggressive therapy [56].

Although in young children AHT is one of the main causes of SDH formation, there certainly is a differential diagnosis. Among others it has been recognized that in children with benign enlargement of the subarachnoid space (BESS) there is an increased risk of developing SDHs, after even a minor trauma, and that thus SHDs are not pathognomonic of AHT in these children [57]. A large retrospective study evaluated a total of 177 children with BESS; in this population $4(2.3 \%)$ were diagnosed with a SDH [58]. All children were evaluated for suspected AHT and in one case healing rib fractures were diagnosed, this patient was subsequently reported to child protective services. This implies that even with a potential benign cause for the presence of a SDH child abuse should be considered. The mechanism, i.e., stretching of anchor veins, as seen in BESS is also present in GA1 and is the cause of an increased risk for SDH development [59]. We found that in only $40 \%$ of included cases AHT was considered and actively eliminated. Acute symptoms of SDHs, e.g., vomiting were the main reason for GA1 diagnosis in $60 \%$ of reported cases. It is worrisome that in $60 \%$ of cases no work-up for child abuse was presented in the case reports, we can only assume that no work-up was performed. It is important to note that the presence of GA1 does not exclude the possibility of abuse as a matter of fact children with metabolic disorders, as are all children with chronic diseases, might be even more vulnerable to AHT [3, 28, 60-63].

The strength of this systematic review is impaired by the fact that most included references were case reports and some case series. However, other study types are unlikely to be performed in this rare patient group. Due to the language restriction relevant articles might have been missed however it is a common approach when performing a literature search to exclude languages. Another issue is 
the variance in the use of terminology in medical literature. In 2009 the AAP has recommended to use the term AHT instead of shaken baby syndrome [2]. As this recommendation does not apply to older literature many different terms are in use, which potentially may lead to cases being missed in the literature search. Also in the field of radiology there are inconsistencies in terminology, terms such as acute subdural hematoma, chronic subdural hematoma, and subdural effusions are used interchangeably [64, 65].

\section{Conclusion}

From this systematic review we conclude that in 19 out 20 cases SDHs in children with GA1 are accompanied by other brain abnormalities specific for GA1. Based on our findings we feel that the time has come to remove GA1, in case of otherwise normal neuroimaging confirmed by a radiologist, as one of the standard differential diagnoses of SDHs in AHT suspicion.

\section{Key points}

1. The relatively high $20-30 \%$ estimated incidence of subdural hematomas in children with GA1 is probably due to frontal lobe atrophy and other brain abnormalities resulting from high levels of neurotoxic intermediate breakdown products.

2. We found a total of 20 cases of subdural hematomas in children with GA1 which have been published since the discovery of this disease in 1975 .

3. 19 out of 20 children in this series with GA1 and SDH had brain pathology which could predispose to later subdural hematoma development. In the one exception abusive head trauma was thought to be possible.

4. There is no supporting evidence for a role of GA1 in medical differential diagnosis of AHT in case of an otherwise normal CT or MRI scan of the brain.

Open Access This article is distributed under the terms of the Creative Commons Attribution 4.0 International License (http://crea tivecommons.org/licenses/by/4.0/), which permits unrestricted use, distribution, and reproduction in any medium, provided you give appropriate credit to the original author(s) and the source, provide a link to the Creative Commons license, and indicate if changes were made.

\section{References}

1. Adamsbaum C, Grabar S, Mejean N, Rey-Salmon C. Abusive head trauma: judicial admissions highlight violent and repetitive shaking. Pediatrics. 2010;126(3):546-55.
2. Christian CW, Block R. Abusive head trauma in infants and children. Pediatrics. 2009;123(5):1409-11.

3. Bishop FS, Liu JK, McCall TD, Brockmeyer DL. Glutaric aciduria type 1 presenting as bilateral subdural hematomas mimicking nonaccidental trauma. Case report and review of the literature. J Neurosurg. 2007;106(3 Suppl):222-6.

4. Brismar J, Ozand PT. CT and MR of the brain in glutaric acidemia type I: a review of 59 published cases and a report of 5 new patients. AJNR Am J Neuroradiol. 1995;16(4):675-83.

5. Haworth JC, Booth FA, Chudley AE, deGroot GW, Dilling LA, Goodman SI, et al. Phenotypic variability in glutaric aciduria type I: report of fourteen cases in five Canadian Indian kindreds. J Pediatr. 1991;118(1):52-8.

6. Hoffmann GF, Athanassopoulos S, Burlina AB, Duran M, de Klerk JB, Lehnert W, et al. Clinical course, early diagnosis, treatment, and prevention of disease in glutaryl-CoA dehydrogenase deficiency. Neuropediatrics. 1996;27(3):115-23.

7. Kohler M, Hoffmann GF. Subdural haematoma in a child with glutaric aciduria type I. Pediatr Radiol. 1998;28(8):582.

8. Woelfle J, Kreft B, Emons D, Haverkamp F. Subdural hemorrhage as an initial sign of glutaric aciduria type 1: a diagnostic pitfall. Pediatr Radiol. 1996;26(11):779-81.

9. Fu Z, Wang M, Paschke R, Rao KS, Frerman FE, Kim JJ. Crystal structures of human glutaryl-CoA dehydrogenase with and without an alternate substrate: structural bases of dehydrogenation and decarboxylation reactions. Biochemistry. 2004;43(30):9674-84.

10. Greenberg CR, Reimer D, Singal R, Triggs-Raine B, Chudley AE, Dilling LA, et al. A G-to-T transversion at the +5 position of intron 1 in the glutaryl CoA dehydrogenase gene is associated with the Island Lake variant of glutaric acidemia type I. Hum Mol Genet. 1995;4(3):493-5.

11. Goodman SI, Stein DE, Schlesinger S, Christensen E, Schwartz $\mathrm{M}$, Greenberg CR, et al. Glutaryl-CoA dehydrogenase mutations in glutaric acidemia (type I): review and report of thirty novel mutations. Hum Mutat. 1998;12(3):141-4.

12. Zschocke J, Quak E, Guldberg P, Hoffmann GF. Mutation analysis in glutaric aciduria type I. J Med Genet. 2000;37(3): 177-81.

13. Kyllerman M, Steen G. Glutaric aciduria. A "common" metabolic disorder? Arch Fr Pediatr. 1980;37(4):279.

14. Lindner M, Kolker S, Schulze A, Christensen E, Greenberg CR, Hoffmann GF. Neonatal screening for glutaryl-CoA dehydrogenase deficiency. J Inherit Metab Dis. 2004;27(6):851-9.

15. Christensen E, Ribes A, Merinero B, Zschocke J. Correlation of genotype and phenotype in glutaryl-CoA dehydrogenase deficiency. J Inherit Metab Dis. 2004;27(6):861-8.

16. Hartley LM, Khwaja OS, Verity CM. Glutaric aciduria type 1 and nonaccidental head injury. Pediatrics. 2001;107(1):174-5.

17. Hedlund GL, Longo N, Pasquali M. Glutaric acidemia type 1. Am J Med Genet C Semin Med Genet. 2006;142C(2):86-94.

18. Chow CW, Haan EA, Goodman SI, Anderson RM, Evans WA, Kleinschmidt-DeMasters BK, et al. Neuropathology in glutaric acidaemia type 1. Acta Neuropathol. 1988;76(6):590-4.

19. Goodman SI, Norenberg MD, Shikes RH. Glutaric aciduria: biochemical and morphologic considerations. J Pediatr. 1977;90(5):746-50.

20. Hoffmann GF, Trefz FK, Barth PG, Bohles HJ, Lehnert W, Christensen E, et al. Macrocephaly: an important indication for organic acid analysis. J Inherit Metab Dis. 1991;14(3):329-32.

21. Kolker S, Garbade SF, Greenberg CR, Leonard JV, Saudubray JM, Ribes A, et al. Natural history, outcome, and treatment efficacy in children and adults with glutaryl-CoA dehydrogenase deficiency. Pediatr Res. 2006;59(6):840-7.

22. Leibel RL, Shih VE, Goodman SI, Bauman ML, McCabe ER, Zwerdling RG, et al. Glutaric acidemia: a metabolic disorder 
causing progressive choreoathetosis. Neurology. 1980;30(11): $1163-8$.

23. Hoffmann GF, Trefz FK, Barth PG, Bohles HJ, Biggemann B, Bremer HJ, et al. Glutaryl-coenzyme A dehydrogenase deficiency: a distinct encephalopathy. Pediatrics. 1991;88(6): 1194-203.

24. Health Council of the Netherlands. Neonatal screening. The Hague: Health Council of the Netherlands; 2005. p. 11.

25. Kolker S, Christensen E, Leonard JV, Greenberg CR, Boneh A, Burlina $\mathrm{AB}$, et al. Diagnosis and management of glutaric aciduria type I-revised recommendations. J Inherit Metab Dis. 2011;34(3):677-94.

26. Twomey EL, Naughten ER, Donoghue VB, Ryan S. Neuroimaging findings in glutaric aciduria type 1. Pediatr Radiol. 2003;33(12):823-30.

27. Strauss KA, Puffenberger EG, Robinson DL, Morton DH. Type I glutaric aciduria, part 1: natural history of 77 patients. Am J Med Genet C Semin Med Genet. 2003;121c(1):38-52.

28. Morris AAM, Hoffmann GF, Naughten ER, Monavari AA, Collins JE, Leonard JV. Glutaric aciduria and suspected child abuse. Arch Dis Child. 1999;80(5):404-5.

29. Cardiff Child Protection Systematic Reviews-CORE INFO. Ranking of exclusion of abuse. http://www.core-info.cardiff.ac. uk/methodology/neurological-injuries/forms-pre-review-and-criticalappraisal. Accessed 22 June 2015.

30. Centre for reviews dissemination. Systematic reviews: CRD's guidance for undertaking reviews in health care: Centre for Reviews and Dissemination; 2009.

31. Singh J. Critical appraisal skills programme. J Pharmacol Pharmacother. 2013;4(1):76.

32. Muntau AC, Roschinger W, Pfluger T, Enders A, Hoffmann GF. Glutaric aciduria type I: two cases of misdiagnosis as battered child syndrome and the importance of presymptomatic diagnosis and treatment. Folgenschwere Fehldiagnose als Kindesmisshandlung. Monatsschrift fur Kinderheilkunde. 1997;145(6): 646-651.

33. Amir N, Elpeleg ON, Shalev RS, Christensen E. Glutaric aciduria type I: enzymatic and neuroradiologic investigations of two kindreds. J Pediatr. 1989;114(6):983-9.

34. Carman KB, Aydogdu SD, Yakut A, Yarar C. Glutaric aciduria type 1 presenting as subdural haematoma. J Paediatr Child Health. 2012;48(8):712.

35. Desai NK, Runge VM, Crisp DE, Crisp MB, Naul LG. Magnetic resonance imaging of the brain in glutaric acidemia type I: a review of the literature and a report of four new cases with attention to the basal ganglia and imaging technique. Invest Radiol. 2003;38(8):489-96.

36. Elsori HA, Naguib KK, Hammoud MS. Glutaric aciduria type 1 in a Kuwaiti infant. East Mediterr Health J. 2004;10(4-5): 680-4.

37. Gago LC, Wegner RK, Capone A Jr, Williams GA. Intraretinal hemorrhages and chronic subdural effusions: glutaric aciduria type 1 can be mistaken for shaken baby syndrome. Retina. 2003;23(5):724-6.

38. Hou LC, Veeravagu A, Hsu AR, Enns GM, Huhn SL. Glutaric acidemia type I: a neurosurgical perspective. Report of two cases. J Neurosurg. 2007;107(2 Suppl):167-72.

39. Kamate M, Patil VD, Chetal V, Hattiholi V. Glutaric aciduria type I-an easily diagnosable and treatable metabolic disorder. Indian J Pediatr. 2009;76(5):562-3.

40. Kim HS, Yu HJ, Lee J, Park HD, Kim JH, Shin HJ, et al. A Korean patient with glutaric aciduria type 1 with a novel mutation in the glutaryl CoA dehydrogenase gene. Ann Clin Lab Sci. 2014;44(2):213-6.

41. Land JM, Goulder P, Johnson A, Hockaday J. Glutaric aciduria type 1 an atypical presentation together with some observations upon treatment and the possible cause of cerebral damage. Neuropediatrics. 1992;23(6):322-6.

42. Lutcherath V, Waaler PE, Jellum E, Wester K. Children with bilateral temporal arachnoid cysts may have glutaric aciduria type 1 (GAT1); operation without knowing that may be harmful. Acta Neurochir (Wien). 2000;142(9):1025-30.

43. Osaka H, Kimura S, Nezu A, Yamazaki S, Saitoh K, Yamaguchi S. Chronic subdural hematoma, as an initial manifestation of glutaric aciduria type-1. Brain Dev. 1993;15(2):125-7.

44. Pfluger T, Weil S, Muntau A, Willemsen UF, Hahn K. Glutaric aciduria type I: a serious pitfall if diagnosed too late. Eur Radiol. 1997;7(8):1264-6.

45. Pusti S, Das N, Nayek K, Biswas S. A treatable neurometabolic disorder: glutaric aciduria type 1. Case Rep Pediatr. 2014;2014:256356.

46. Singh S, Chowdhury V, Dixit R, Prakash A, Agarwal A. Glutaric aciduria type I: a case report. Indian $\mathrm{J}$ Radiol Imaging. 2006;16(4):723-6.

47. Knapp JF, Soden SE, Dasouki MJ, Walsh IR. A 9-month-old baby with subdural hematomas, retinal hemorrhages, and developmental delay. Pediatr Emerg Care. 2002;18(1):44-7.

48. Zielonka M, Braun K, Bengel A, Seitz A, Kolker S, Boy N. Severe acute subdural hemorrhage in a patient with glutaric aciduria type I after minor head trauma: a case report. J Child Neurol. 2015;30:1065-9.

49. Forbes BJ, Rubin SE, Margolin E, Levin AV. Evaluation and management of retinal hemorrhages in infants with and without abusive head trauma. J AAPOS. 2010;14(3):267-73.

50. Maguire SA, Watts PO, Shaw AD, Holden S, Taylor RH, Watkins WJ, et al. Retinal haemorrhages and related findings in abusive and non-abusive head trauma: a systematic review. Eye (Lond). 2013;27(1):28-36.

51. Thompson AK, Bertocci G, Rice W, Pierce MC. Pediatric shortdistance household falls: biomechanics and associated injury severity. Accid Anal Prev. 2011;43(1):143-50.

52. Strauss KA, Donnelly P, Wintermark M. Cerebral haemodynamics in patients with glutaryl-coenzyme A dehydrogenase deficiency. Brain. 2010;133:76-92.

53. Martinez-Lage JF. Neurosurgical treatment for hydrocephalus, subdural hematomas, and arachnoid cysts in glutaric aciduria type 1. Neuropediatrics. 1996;27(6):335-6.

54. Martinez-Lage JF, Casas C, Fernandez MA, Puche A, Rodriguez Costa T, Poza M. Macrocephaly, dystonia, and bilateral temporal arachnoid cysts: glutaric aciduria type 1. Childs Nerv Syst. 1994;10(3):198-203.

55. Garbade SF, Greenberg CR, Demirkol M, Gokcay G, Ribes A, Campistol J, et al. Unravelling the complex MRI pattern in glutaric aciduria type I using statistical models-a cohort study in 180 patients. J Inherit Metab Dis. 2014;37:763-73.

56. Cho $\mathrm{CH}$, Mamourian AC, Filiano J, Nordgren RE. Glutaric aciduria: improved MR appearance after aggressive therapy. Pediatr Radiol. 1995;25(6):484-5.

57. McNeely PD, Atkinson JD, Saigal G, O'Gorman AM, Farmer JP. Subdural hematomas in infants with benign enlargement of the subarachnoid spaces are not pathognomonic for child abuse. AJNR Am J Neuroradiol. 2006;27(8):1725-8.

58. McKeag H, Christian CW, Rubin D, Daymont C, Pollock AN, Wood J. Subdural hemorrhage in pediatric patients with enlargement of the subarachnoid spaces. J Neurosurg Pediatr. 2013;11(4):438-44.

59. Piatt JH Jr, Frim D. Glutaric aciduria type 1 and nonaccidental head injury. Pediatrics. 2002;109(3):554.

60. Hershkowitz I, Lamb ME, Horowitz D. Victimization of children with disabilities. Am J Orthopsychiatry. 2007;77(4):629-35.

61. Jaudes PK, Mackey-Bilaver L. Do chronic conditions increase young children's risk of being maltreated? Child Abuse Negl. 2008;32(7):671-81. 
62. Waldman HB, Swerdloff M, Perlman SP. A "dirty secret": the abuse of children with disabilities. ASDC J Dent Child. 1999;66(3):197-202, 155.

63. Westcott $\mathrm{H}$. The abuse of disabled children: a review of the literature. Child Care Health Dev. 1991;17(4):243-58.

64. Hobbs C, Childs AM, Wynne J, Livingston J, Seal A. Subdural haematoma and effusion in infancy: an epidemiological study. Arch Dis Child. 2005;90(9):952-5.
65. Minns RA, Busuttil A, LeFanu J, Edwards-Brown R. Patterns of presentation of the shaken baby syndrome: four types of inflicted brain injury predominate. BMJ. 2004;328(7442):766-7. 